\title{
Analysis of Consumer Purchasing Decisions through Product Quality and Promotion on Pam Pam Fried Chicken Products in the District of Pamulang, South Tangerang City
}

\author{
Udin Ahidin \\ Universitas Pamulang \\ Email: dosen00406@unpam.ac.id
}

(Received: march 10-2020; revised: June 15-2020; published: June 30-2020)

\begin{abstract}
This study is to determine the effect of product quality partially on consumer purchasing decisions on Pam Pam Fried Chicken in Pamulang Subdistrict Area, to determine the effect of partial promotion on consumer purchasing decisions on Pam Pam Fried Chicken in Pamulang Subdistrict Area, to determine the effect of product quality and promotion together with consumer purchasing decisions on Pam Pam Fried Chicken in the Pamulang District Area, and to find out the company's efforts to improve consumer purchasing decisions on Pam Pam Fried Chicken in the Pamulang District Region .Quantitative associative research methods with a verification approach. The population in this study Pam-Pam Fried Chicken consumers amounted to 7,108 consumers in the District of Pamulang, while the sample taken was 100 respondents using the slovin formula, then a proportional random sampling was done because the research object contained 4 (four) branches. Collecting observational data, questionnaires and literature studies. The data analysis method uses validity test, reliability test, classic assumption test, simple linear regression test, multiple linear regression test, correlation coefficient test (product moment), determination coefficient test, hypothesis test (t-test and f-test). The results showed that there was a positive and significant effect between product quality partially on purchasing decisions. It can be seen from the simple linear regression coefficient of 0.65 . The coefficient of determination is $0.6 \%, \mathrm{t}_{\text {coum }} 2.719>$ $\mathrm{t}$ able 1.984 . There is a positive and significant influence between promotion partially on purchasing decisions. It can be seen from the simple linear regression coefficient of 0.32 . The coefficient value of determination is $0.2, \mathrm{t}_{\text {coum }} 2.112>\mathrm{t}_{\text {able }} 1.984$.
\end{abstract}

Keywords: Product Quality; Promotion; Purchasing Decisions

\section{INTRODUCTION}

Increasing complexity of consumer desires leads to a necessity for companies in various industries, must be able to fulfill these desires (AL-Sinawi, Piaw, \& Idris, 2015; Brown, Gray, McHardy, \& Taylor, 2015). This is of course by using the ability to innovate so that the products offered are more attractive and superior. This is a tactic in winning the increasingly high competition in an increasingly technological era.

Nowadays, processed product companies face very tight competition. In which the presence of free trade can affect the market demand and competition has become very tight. Increasing the intensity of competition and the number of competitors, each company is required to always compete in attracting consumers, especially in providing products with better quality than those carried out by competitors. Therefore, companies must be clever in 


\footnotetext{
92| Jurnal Ilmiah Ilmu Administrasi Publik: Jurnal Pemikiran dan Penelitian Administrasi Publik Volume 1o Number 1, January- june 2020. Page 91-98
}

determining policies in order to increase consumer interest in buying products that affect the increase in corporate profits and better company survival (Ferrara, Missios, \& Yildiz, 2019; Morris, 1980) .

Companies that aim to provide the highest satisfaction for consumers will strive to provide and offer quality, clean, healthy and halal products (Ferrara et al., 2019; Han \& Chouinard, 2014; van Ooijen, Fransen, Verlegh, \& Smit, 2017). Because products with good quality, which can satisfy and win the hearts of consumers in making purchasing decisions on the quality of products offered. To achieve the desired product quality it is necessary to standardize quality. This method is intended to ensure that the products produced meet the established standards so that consumers will not lose trust in the product concerned (Curzi, Schuster, Maertens, \& Olper, 2020; Zhang, Wang, \& Xu, 2019) .

Marketers who do not pay attention to the quality of the products offered will bear the disloyalty of consumers so that the sales of their products will tend to decline. According to (Kotler \& Keller, 2009), states that "Product quality is the ability of a product to carry out its functions, including reliability, durability, accuracy, ease of operation, and product improvement". Meanwhile, in the opinion (Kotler and Armstrong, 2008), product quality is a characteristic of a product or service that depends on its ability to satisfy the expressed or implied needs of customers. The purpose of product quality is to convince consumers that the product is the best according to consumer needs. To make it even more convincing there are companies that dare to be compensated if their products are not of quality or not in accordance with the promotions that are delivered (Ariani, 2016; Diza, 2016; Mulyono, Yoestini, Nugraheni, \& Kamal, 2007) . On the other hand Kotler (2013) states that no matter how good a product is, if the company does not inform them of a promotional program, consumers will not know it. Therefore the promotional program is very important to be carried out by the Pam Pam Fried Chicken in the District of Pamulang.

\section{Table 1}

Pam Pam Fried Chicken Consumer Data in the District of Pamulang District

\begin{tabular}{clccccccc}
\hline No & Branch Name & 2014 & 2015 & 2016 & 2017 & 2018 & amount & $\begin{array}{c}\text { Sales } \\
(\%)\end{array}$ \\
\hline 1 & Reni Jaya & 237 & 285 & 329 & 375 & 448 & 1,674 & 23 \\
2 & Griya Jakarta & 345 & 351 & 416 & 331 & 475 & 1,918 & 26 \\
3 & Pigeon Pamulang & 421 & 394 & 403 & 247 & 322 & 1,787 & 25 \\
4 & Vila Dago & 312 & 424 & 248 & 443 & 302 & 1,729 & 24 \\
& $\quad$ & & & & & 7,108 & \\
\hline
\end{tabular}

Sumber: Pam Pam Fried Chicken di Wilayah Kecamatan Pamulang (2019).

From the table above shows that there was a decrease in the level of visits to Pam Pam Fried Chicken in the District of Pamulang. This is an indication of the level of purchasing decisions over the past 5 (five) years. Decrease in the level of purchase decisions above is thought to be caused by many factors, one of which is the quality of Pam Pam Fried Chicken products if viewed from the number of flavors is still relatively small, it is as in table 2. 
Table 2

Featured Data Pam Pam Fried Chicken Flavor Variant in Pamulang District Area

\begin{tabular}{llll}
\hline No & Pam Pam Fried Chicken Flavor Variant & No & \multicolumn{1}{c}{$\begin{array}{c}\text { Variant Sense of } \\
\text { Competitors }\end{array}$} \\
\hline 1 & Original (Sauce: Sambel, Spicy and Cheese). & 1 & Original \\
& & 2 & Spicy \\
& & 3 & Salty \\
& & 4 & Cheese \\
& & 5 & Black pepper \\
\hline
\end{tabular}

Source: Observation results (2019).

Based on the information from table 2 above, it is found that the features of Pam Pam Fried Chicken flavor variants in the Pamulang Sub-District region are less compared to competitors. This allows consumers to be more attracted to competitors who offer more variant flavors. The level of consumer purchasing decisions on Pam Pam Fried Chicken products in the Pamulang Sub-District region is declining in addition to being allegedly caused by the quality of products under competing, also allegedly caused by promotion programs that have not been maximized. It can be seen empirical phenomenon data in table 3.

Table 3

Pam Pam Fried Chicken Promotion Program Data in the District Area

\begin{tabular}{lllllllll}
\hline No & $\begin{array}{l}\text { Promotion } \\
\text { Program }\end{array}$ & $\mathbf{2 0 1 4}$ & $\mathbf{2 0 1 5}$ & $\mathbf{2 0 1 6}$ & $\mathbf{2 0 1 7}$ & $\mathbf{2 0 1 8}$ & Information \\
\hline 1 & $\begin{array}{l}\text { Advertising } \\
\text { Sales }\end{array}$ & $\sqrt{ }$ & & $\sqrt{ }$ & & $\sqrt{ }$ & Not maximal \\
2 & & $\sqrt{ }$ & $\sqrt{ }$ & & & Not maximal \\
& $\begin{array}{l}\text { promotion } \\
3\end{array}$ & & & $\sqrt{ }$ & & $\sqrt{ }$ & $\sqrt{ }$ & Almost the maximum \\
& $\begin{array}{l}\text { Personal } \\
4\end{array}$ & Sales & & $\sqrt{ }$ & & & & \\
Publicity & & $\sqrt{ }$ & $\sqrt{ }$ & & $\sqrt{ }$ & Not maximal \\
5 & $\begin{array}{l}\text { Direct } \\
\text { Marketing }\end{array}$ & $\sqrt{ }$ & $\sqrt{ }$ & & $\sqrt{ }$ & $\sqrt{ }$ & Almost the maximum \\
\hline
\end{tabular}

Source: Pam Pam Fried Chicken in the District of Pamulang District (2019).

Information from table 3 above, it can be seen that the promotion program conducted by Pam Pam Fried Chicken in the District of Pamulang has not been maximally carried out, so it is allegedly one of the causes of consumer purchasing decisions to decline. That is as explained by (Kotler, 2013), that no matter how good the product is, consumers will not know about it, consumers will not buy it if the company does not make an intensive promotion.

\section{METHOD}

The research method used is quantitative associative with a verification approach. The object of this research is Pam Pam Fried Chicken in the District of Pamulang, which is a company engaged in the field of food. Its center is located on Jl. Alam Segar No.2, Bambu 
94 Jurnal Ilmiah Ilmu Administrasi Publik: Jurnal Pemikiran dan Penelitian Administrasi Publik Volume 1o Number 1, January- june 2020. Page 91-98

Apus, Pamulang, Kota Tangerang Selatan, Banten 15415 tel 087771797800 . The population of this study is all consumers of Pam Pam Fried Chicken in the Pamulang District Area taken from 4 branches or outlets as many as 7,108 people. The sample in this study were 100 respondents taken by proportional random sampling. Data collection methods in this research are observation, questionnaire study and literature study. The data analysis methods are validity test, reliability test, classic assumption test, simple linear regression, multiple regression test, product moment correlation test, determination test, and hypothesis test ( $\mathrm{t}$ test and $\mathrm{f}$ test).

\section{RESULT AND DISCUSSION}

To achieve the desired product quality it is necessary to standardize quality. This method is intended to ensure that the products produced meet the established standards so that consumers will not lose confidence in the product concerned.

\section{Simple Regression Test Between Product Quality and Consumer Purchasing Decisions}

\section{Table 4}

Simple Linear Regression Test Results

\begin{tabular}{|c|c|c|c|c|c|c|}
\hline & & \multicolumn{3}{|c|}{ Coefficients $^{\mathrm{a}}$} & \multirow[b]{3}{*}{$\mathrm{t}$} & \multirow[b]{3}{*}{ Sig. } \\
\hline \multirow[b]{2}{*}{ Model } & & \multicolumn{2}{|c|}{$\begin{array}{l}\text { Unstandardized } \\
\text { Coefficients }\end{array}$} & $\begin{array}{l}\text { Standardized } \\
\text { Coefficients }\end{array}$ & & \\
\hline & & $\mathrm{B}$ & Std. Error & Beta & & \\
\hline 1 & (Constant) & 36.593 & 3.955 & & 9.253 & .000 \\
\hline & $\begin{array}{l}\text { Product } \\
\text { quality }\end{array}$ & .065 & .084 & .078 & .775 & .440 \\
\hline
\end{tabular}

a. Dependent Variable: Purchase Decision

Source: Processed Results of SPSS Data 22 (2019).

Based on the table above, the regression equation in the form of this regression test is : $\mathrm{Y}$ $=36,593+0.65 \mathrm{X}_{1}$

Based on the equation it can be seen that a constant value of 36,593 means that without the quality of the product the purchase decision will still be worth 36.593. Regression coefficient value of 0.65 product quality variable $\neq 0$ and air- mark positively have meaning there is positive between the quality of products on purchase decisions Pam-Pam Fried Chicken in Pamulang District Area.

Based on the results of the data processing above, a research model is formed that is directly proportional between the quality of the product to the purchase decision, that is if the product quality is good, the purchasing decision rises, the regression coefficient number is positive.

\section{Simple Review Test Between Promotion and Consumer Purchasing Decisions}


Table 5 .

Simple Linear Regression

Coefficients $^{\text {a }}$

\begin{tabular}{|c|c|c|c|c|c|c|}
\hline \multirow[b]{2}{*}{ Model } & & \multicolumn{2}{|c|}{$\begin{array}{c}\text { Unstandardized } \\
\text { Coefficients }\end{array}$} & \multirow{2}{*}{$\begin{array}{c}\text { Standardized } \\
\text { Coefficients } \\
\text { Beta } \\
\end{array}$} & \multirow[b]{2}{*}{$\mathrm{t}$} & \multirow[b]{2}{*}{ Sig. } \\
\hline & & $\mathrm{B}$ & Std. Error & & & \\
\hline 1 & (Constant) & 38,379 & 3,218 & & 11,925 & .000 \\
\hline & Promotion & .032 & .082 & .040 & .395 & .694 \\
\hline
\end{tabular}

a. Dependent Variable: Purchase Decision

Source: Processed Results of SPSS Data 22 (2019).

According to the table above, the regression equation formed in regression is : $\mathrm{Y}=38$ $379+0.32 \mathrm{x}_{2}$

Based on the equation can be in the know that $n$ use values constant at 38.379 means that without the quality of the product, the purchasing decision will still be worth 38.379 . Variable regression coefficient value product quality by $0.32 \neq 0$ and air- mark positively have meaning there is positive between the quality of products on purchase decisions Pam-Pam Fried Chicken in Pamulang District Area.

Based on the results of the data processing above, a research model is formed that is based on a straight line between promotion and purchasing decisions, i.e. if the promotion is intense, the purchase decision increases, the regression coefficient is positive.

\section{Multiple Regression Test Between Product Quality and Promotion of Consumer Purchasing Decisions}

Table 6 .

Multiple Linear Regression

Coefficients ${ }^{\text {a }}$

\begin{tabular}{|c|c|c|c|c|c|c|}
\hline \multirow[b]{2}{*}{ Model } & & \multicolumn{2}{|c|}{$\begin{array}{c}\text { Unstandardized } \\
\text { Coefficients }\end{array}$} & \multirow{2}{*}{$\begin{array}{c}\text { Standardized } \\
\text { Coefficients } \\
\text { Beta }\end{array}$} & \multirow[b]{2}{*}{$\mathrm{t}$} & \multirow[b]{2}{*}{ Sig. } \\
\hline & & $\mathrm{B}$ & Std. Error & & & \\
\hline \multirow[t]{3}{*}{1} & (Constant) & 36,000 & 5,093 & & 7,069 & .000 \\
\hline & $\begin{array}{l}\text { Product } \\
\text { quality }\end{array}$ & .034 & .082 & .042 & 2,719 & .000 \\
\hline & Promotion & .50 & .081 & .062 & 2,112 & .000 \\
\hline
\end{tabular}

a. Dependent Variable: Purchase Decision

Source: Processed Results of SPSS Data 22 (2019).

According to the table above, the regression equation in the form on this regression is $\mathrm{Y}=$ $36,000+0.34 \mathrm{X}_{1}+0.50 \mathrm{X}_{2}$.

Based on the equation it can be seen that a constant value of 36,000 means that without product quality and promotion, the purchasing decision will still be worth 36,000 . The value of the variable regression coefficient 1 product quality of $0.34 \neq 0$ positive signified means that if 
96 Jurnal Ilmiah Ilmu Administrasi Publik: Jurnal Pemikiran dan Penelitian Administrasi Publik Volume 10 Number 1, January- june 2020. Page 91-98

the quality of the product increases, it will increase purchasing decisions and vice versa. Promotional variable regression coefficient value of $0: 50 \neq 0$ Air sign positive $\mathrm{j}$ has the meaning ika campaign carried out by the company maximum will increase the purchasing decisions and vice versa.

Based on the results of the data above, a research model is formed that is directly proportional between product quality and promotion of purchasing decisions, i.e. if the product quality is good and promotions are carried out intensively, then the purchase decision rises, the positive regression coefficient numbers.

Test Results of Partial Significance of Product Quality on Consumer Purchasing Decisions (t Test)

Table 7

Significance Test (t Test)

Coefficients $^{\mathbf{a}}$

\begin{tabular}{|c|c|c|c|c|c|c|}
\hline \multirow[b]{2}{*}{ Model } & & \multicolumn{2}{|c|}{$\begin{array}{l}\text { Unstandardized } \\
\text { Coefficients }\end{array}$} & \multirow{2}{*}{$\begin{array}{c}\text { Standardized } \\
\text { Coefficients } \\
\text { Beta } \\
\end{array}$} & \multirow[b]{2}{*}{$\mathrm{t}$} & \multirow[b]{2}{*}{ Sig. } \\
\hline & & $\mathrm{B}$ & Std. Error & & & \\
\hline \multirow[t]{3}{*}{1} & (Constant) & 36.000 & 5.093 & & 7.069 & .000 \\
\hline & Product quality & .034 & .082 & .042 & 2.719 & .000 \\
\hline & Promotion & .050 & .081 & .062 & 2.112 & .000 \\
\hline
\end{tabular}

a. Dependent Variable: Purchase Decision

Source: Processed Results of SPSS Data 22 (2019).

Based on $\mathrm{t}$ test results table above, it can be seen that $\mathrm{n}$ use values th counted as product quality of $\mathrm{t}$ count $2.719>\mathrm{t}$ table 1.984 with significant $0,000<0.05$ then $\mathrm{H}_{0}$ is rejected and $\mathrm{H}_{\text {a }}$ received indicates that the quality of the product $\left(X-{ }_{1}\right)$ have influence which is positive and significant towards the buying decision (Y). Promotional $t$ value of $t$ count $2,112>t$ table 1.984 with significant $0,000<0.05$ then $\mathrm{H}_{0}$ is rejected and $\mathrm{H}_{\text {a }}$ received indicates that the sale $\left(\mathrm{X}_{2}\right)$ has a positive and significant influence on purchasing decisions (Y). Significant meaning means that the opinions of a sample of 100 respondents are representative or represent a population of 7,108 people. So that the results of this study can be applied in all Pam-Pam Fried Chiken branches in the Pamulang District Area.

Test Results of Simultaneous Significance of Product Quality on Consumer Purchasing Decisions (Test F)

Table 8 .

F test count

ANOVA ${ }^{\text {a }}$ 


\begin{tabular}{llrrrrr}
\hline Model & & \multicolumn{1}{c}{ Sum of } & \multicolumn{2}{c}{ Mean } \\
\hline 1 & Rquares & Df & Square & \multicolumn{1}{c}{ F } & \multicolumn{1}{c}{ Sig. } \\
\hline & Regression & 8,842 & 2 & 4,421 & 3,264 & $.768^{\mathrm{b}}$ \\
& Residual & 1623,998 & 97 & 16,742 & & \\
& Total & 1632,840 & 99 & & & \\
\hline
\end{tabular}

a. Dependent Variable: Purchase Decision

b. Predictors: (Constant), Promotion, Product Quality

Source: Processed Results of SPSS Data 22 (2019).

Based on the results of the data processing table above shows the results of the calculation of $U$ ji $F$ obtained calculated $F$ value of 3,264 with a significance level of $0.00<0.05$.

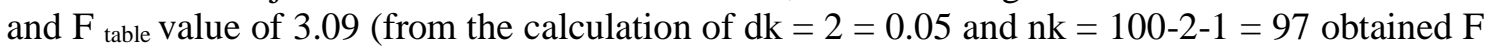
table 3.09). This means that Fcount 3.264> F table 3.09, thus Ho is rejected and $\mathrm{Ha}$ is accepted, meaning that product quality and promotion have a simultaneous and significant effect on purchasing decisions. Significant meaning means that the opinions of a sample of 100 respondents are representative or represent a population of 7,108 people. So that the results of this study can be applied in all Pam-Pam Fried Chiken branches in the Pamulang District Area.

\section{CONCLUSION}

Based on the results of the study it was found that there is a positive and significant influence between product quality on purchasing decisions. There is a positive and significant influence between promotions on purchasing decisions. There is a positive and significant effect between product quality and promotion on purchasing decisions .

\section{REFERENCES}

AL-Sinawi, S., Piaw, C. Y., \& Idris, A. R. (2015). Factors Influencing the Employees' Service Performance in Ministry of Education in Sultanate of Oman. Procedia - Social and Behavioral Sciences, $197, \quad 23-30$. https://doi.org/https://doi.org/10.1016/j.sbspro.2015.07.043

Ariani, W. (2016). Manajemen Kualitas. Jurnal Managemen.

Brown, S., Gray, D., McHardy, J., \& Taylor, K. (2015). Employee trust and workplace performance. Journal of Economic Behavior \& Organization, 116, 361-378. https://doi.org/https://doi.org/10.1016/j.jebo.2015.05.001

Curzi, D., Schuster, M., Maertens, M., \& Olper, A. (2020). Standards, trade margins and product quality: Firm-level evidence from Peru. Food Policy, 91, 101834. https://doi.org/https://doi.org/10.1016/j.foodpol.2020.101834

Diza, F. (2016). Pengaruh Kualitas Pelayanan, Kualitas Produk Dan Kepercayaan Terhadap Kepuasan Konsumen (Studi Pada Pt. Fifgroup Cabang Manado). Jurnal Riset Ekonomi, 
98| Jurnal Ilmiah Ilmu Administrasi Publik: Jurnal Pemikiran dan Penelitian Administrasi Publik Volume 1o Number 1, January- june 2020. Page 91-98

Manajemen, Bisnis Dan Akuntansi.

Ferrara, I., Missios, P., \& Yildiz, H. M. (2019). Product quality, consumption externalities, and the role of National Treatment. European Economic Review, 117, 1-35. https://doi.org/https://doi.org/10.1016/j.euroecorev.2019.04.005

Han, B., \& Chouinard, H. H. (2014). Product quality, advertising intensity and market size. Economics Letters, 124(2), 215-218. https://doi.org/https://doi.org/10.1016/j.econlet.2014.05.020

Kotler. (2013). Manajemen Pemasaran Jilid 2. In Penerbit Erlangga.

Kotler dan Amstrong. (2008). Prinsip-Prinsip Pemasaran Jilid I. In Erlangga.

Kotler, P., \& Keller, K. L. (2009). Marketing management (13th ed.). In Prentice Hall.

Morris, D. (1980). A note on pricing and promotional strategies for a firm operating in dual markets. Omega, 8(6), 699-700. https://doi.org/https://doi.org/10.1016/03050483(80)90014-6

Mulyono, B. H., Yoestini, Nugraheni, R., \& Kamal, M. (2007). Analisis Pengaruh Kualitas Produk Dan Kualitas Layanan Terhadap Kepuasan Konsumen (Studi Kasus Pada Perumahan Puri Mediterania Semarang). Jurnal Studi Manajemen \& Organisasi.

van Ooijen, I., Fransen, M. L., Verlegh, P. W. J., \& Smit, E. G. (2017). Packaging design as an implicit communicator: Effects on product quality inferences in the presence of explicit quality cues. Food Quality and Preference, 62, 71-79. https://doi.org/https://doi.org/10.1016/j.foodqual.2017.06.007

Zhang, Z., Wang, P., \& Xu, H. (2019). Executives' preference for integrity and product quality: Evidence from the Chinese food industry. Economic Modelling. https://doi.org/https://doi.org/10.1016/j.econmod.2019.11.026 